\title{
GMP/GACP - new standards for quality assurance of cannabis
}

\author{
Mirela Ilikj ${ }^{1}$, Irena Brchina ${ }^{1}$, Liljana Ugrinova ${ }^{2}$, Vasil Karcev ${ }^{2}$, \\ Aleksandra Grozdanova ${ }^{3}$ \\ ${ }^{I}$ NYSK Holdings-Skopje, Industry for extracts and pharmaceutical dosage forms of cannabis for medical use, \\ Industrial Zone Kojlija, Municipality of Petrovec, 1000 Skopje, North Macedonia \\ ${ }^{2}$ Institute of Applied Chemistry and Pharmaceutical Analysis, Faculty of Pharmacy, \\ Ss. Cyril and Methodius University, Majka Tereza 47, 1000 Skopje, North Macedonia \\ ${ }^{3}$ Institute of Pharmaceutical Chemistry, Faculty of Pharmacy, \\ Ss. Cyril and Methodius University, Majka Tereza 47, 1000 Skopje, North Macedonia
}

Received: November 2019; Accepted: December 2020

\begin{abstract}
In 2015, in Republic of North Macedonia, a new law for narcotics has been adopted, where the changes include legal cultivation of cannabis for medicinal use as well as legal production of cannabis extracts for medicinal use. In order to gain high quality of cannabis and cannabis products for medicinal use and to meet some quality standards that will guarantee consistency, traceability and continuous quality of the product, it is necessary to implement Quality Systems. Good quality system is ISO standard system but for cannabis for medicinal use, GACP, GMP and GLC standards are used more often. Production of cannabis for medicinal use consists of: process of cultivation where GACP standards are applicable, primary processing where GMP standards are the most important and quality control of final product regulated with GLP standard.

In this review, explanation of these standards as well as overview of modes of their implementation has been made.
\end{abstract}

Keywords: GxP, GMP, GACP, GLP

\section{Introduction}

Standards present in standardized production for the purpose of obtaining good quality cannabis products through a permanent, unified and stable system are:

1. Good Practices (GxP) ("x" can be replaced by agriculture, revision, documentation, manufacturing, clinical, distribution, laboratory, storage, etc.) are recommended working procedures and methodologies that are applied for gaining effective, accurate, reliable, consistent and pure active substance, medicinal product or medical device, which should continuously meet the defined quality criteria implemented in a strict and controlled manner, including research and development, production processes, quality control, storage and distribution. The main aspects of GxP are: quality, integrity, traceability and responsibility. Documentation is a critical tool to be used as part of the implementation of the GxP compliance (WHO, 2003).

2. Good Manufacturing Practices (GMP) are manufacturing and administrative procedures and practices that ensure medicinal products meet the required production standards/marketing authorization

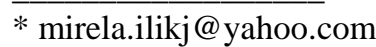


requirements, product specifications, and customer expectations in order to ensure a safe and efficient final product. There are ten basic principles of GMP: proper design, construction and maintenance of the facility, utilities and equipment, validation of equipment, production processes, cleaning, test methods and software system, preparation of Standard Operative Procedures (SOPs) and their monitoring, accurate documentation, employee training, protection and prevention of contamination, health/hygiene of employees, constant quality in the entire life cycle of the product and audits/inspections (WHO, 1996a).

3. Good Laboratory Practice (GLP) regulations are international standards relevant to research, development and quality control (QC) laboratories aimed at supporting the development of quality and validated test data used to certify the safety and compatibility of the product specification. GLP includes: general requirements, requirements for facilities, equipment requirements and SOPs. Analytical testing in the medical cannabis area is a critical part of quality control and rapid field development. Cannabis testing laboratories follow the quality systems specified in ISO 17025, which aims to provide conditions for the laboratory to be responsible for its activities (testing, calibration and sampling) using standard methods, non-standard methods and internal methods (WHO, 1998).

4. Good Agricultural Practice and Practice of Collecting Medicinal Plants (GACP) - within the overall context of quality assurance, GACPs for medicinal plants are primarily intended to provide general technical guidance for obtaining quality medicinal plant materials for the sustainable production of herbal products classified as medicines. The cultivation, collection and harvesting of medicinal plants, as well as the processing of medicinal plant materials after harvest, must be carried out in accordance with the legal and environmental requirements of the country in which the activities are carried out (WHO, 1996b).

The implementation of GACP, GMP and GLP quality standards in herbal extraction is simple and
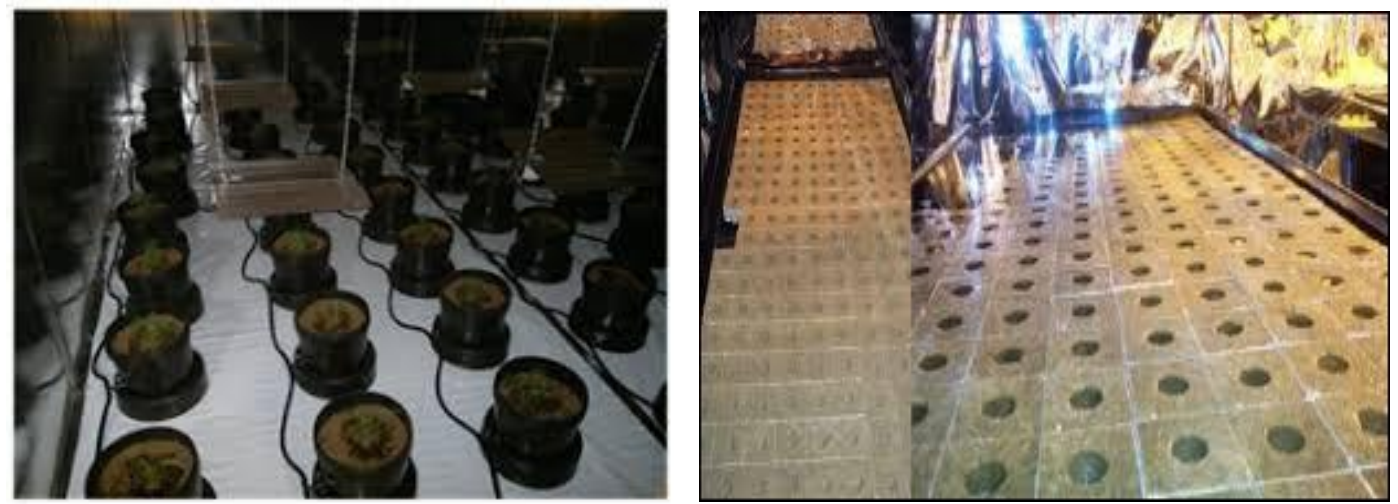

Fig. 1. In-door cultivation of cannabis for medicinal use. familiar pharmaceutical process but the implementation of GACP, GMP and GLP quality standards in process of cannabis cultivation is a challenge.

That's why the aim of this paper is to make an overview of the implementation of GACP and GMP into the cultivation of medicinal cannabis and production of final cannabis product with highest quality.

\section{Strategy and approach in applying GACP/GMP standards in the cultivation and production of cannabis for medical use}

The continuous quality of medicinal plants/herbal substances from cannabis could be ensured by establishing GACP. The production, processing, packaging and storage of active pharmaceutical ingredients (APIs) as well as medicinal plants/herbal substances relies on GMP standards. The quality of herbal preparations depends on production and primary treatment of medicinal plants/herbal substances as API. As a result of the complexity of naturally grown medicinal herbs/herbal substances and limited analytical techniques for determining the ingredients by chemical and biological methods, the repetition of the quality of initial materials of plant origin depends on the appropriate quality assurance system for collection and/or cultivation, harvest and primary processing.

The safety and the quality of raw medicinal herbal materials and finished products depend on factors that can be classified as: essential (genetic) or external factors (ecological environment and impact, climatic conditions, soil, irrigation and drainage, maintenance and protection of herbs, methods for collection, cultivation, harvesting, transport and storage).

GACP provide additional standards for the production and processing of medicinal plants/herbal cannabis substances with a major focus on identifying those critical production steps that are needed to ensure the required quality and safety for consumption. 
The cultivation of cannabis for medicinal use could be performed on external conditions - outdoor or greenhouses or on internal conditions - in door. When cannabis cultivation and harvesting is performed in external conditions - outdoor or in greenhouses, medical plant materials derived from the same type of cannabis can show significant differences in quality, i.e. in physical appearance and variations in composition, depending on external environmental conditions, including ecological and geographical variables. On the opposite, the advantages of in door production (Fig. 1) over production in the external conditions are many: insignificant influence of all natural factors on the quality and the quantitative yield, maximum and automatic control (24/7) on all conditions in the premises such as: UV light, adequate ventilation, temperature and humidity, controlled watering and plant nutrition as well as controlled $\mathrm{pH}$ values of the substrate (Fig. 2), maximum protection and pest control (insects, rodents, animals and birds) and maximum protection against dust, allergens and other particles (Ministry of Health, Labour and Welfare Ed. Yakuji Nippo, 1992-2001).

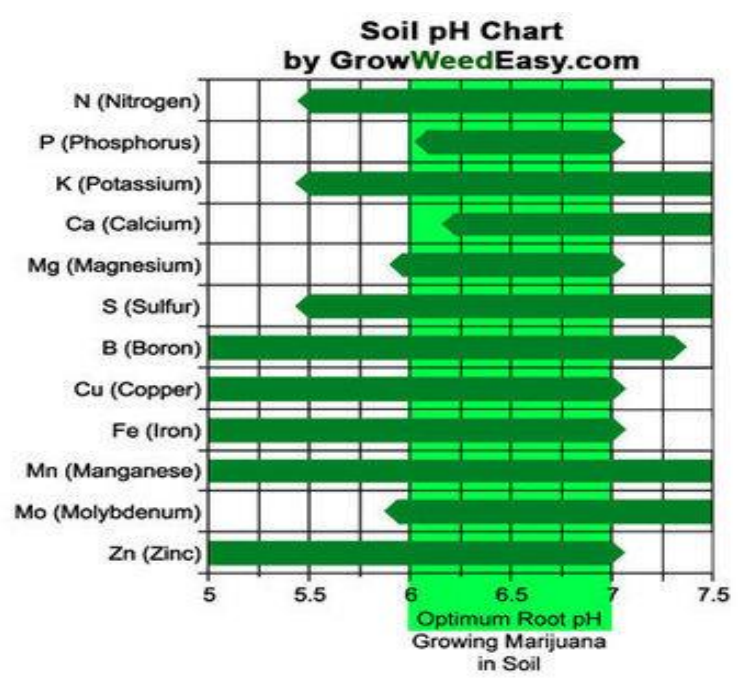

Fig. 2. Fertilization and $\mathrm{pH}$ of the soil - essential factors for cultivation of cannabis for medicinal use.

\section{Quality assurance}

Written contracts made between producers and buyers of medicinal plants/herbal substances derived from cannabis with appropriate quality - specified content of active principle, macroscopically and olfactory properties, limit values for microbial contamination, chemical residues and heavy metals etc., should comply with recognized regional and/or national specifications (EMA, 2006).

\section{Manager's responsibilities}

All managers should fully understand their responsibilities to ensure a safe and healthy working environment and possess the appropriate qualifications to meet the requirements assigned to them. They should provide a documented system to provide evidence of procedures carried out in accordance with regional and/or national law and regulations, to have a plan and program to ensure business continuity and environmental protection, to ensure risks management system, possess organizational scheme that identifies all levels, job positions and responsibilities.

\section{Facilities and premises}

The facilities and premises for the cultivation and primary processing of cannabis must have a valid authorization in accordance with national law. Changing rooms, toilets and hand-washing devices should be clean, well-equipped and easily accessible for employee, but also far enough away from the production premises (to exclude contamination of the product). The buildings used to process collected medicinal herbs/cannabis herbal substances must be clean, well ventilated, with solid foundations and never used for the storage of livestock. They must be adequately protected against birds, insects, rodents and domestic animals. Appropriate pest control measures, such as baits and electric insect destruction devices, should be carried out in all warehouses and processing sites and handled and maintained by trained personnel or contracting parties. Water distribution system should start from adequate storage facility, made of high quality materials and with adequate chemical and/or thermal protection against contamination.

Appropriate natural or artificial lighting should be installed throughout the building. Where appropriate, lighting must not change colors and the intensity should not be less than 540 lux in all inspection places, 220 lux in the office and 110 lux in other areas. The spectator must be of high quality, so that yields and cannabinoid profiles are consistent and so that their light power does not decay rapidly and dramatically, influencing yields. Distribution of the wavelength must remain without significant changes over the whole life of the lamps in order to provide consistent yields. LED lights are often placed really close to the flowers as an excellent strategy for minimizing the loss of precious photons. The lamps placed in the cultivation premises should be made of nontoxic materials, antibacterial, placed in metal frames, which should be inserted into the ceiling panels, thus achieving the same level with the ceiling that results in a flat surface easy to maintain and clean.

The space for the cultivation/production of medical cannabis should be divided into several whole, logically, horizontally, connected by the processes ( phases), premises: Separate premise (baby room) for clones (varieties) - clones are obtained by selecting and cutting 


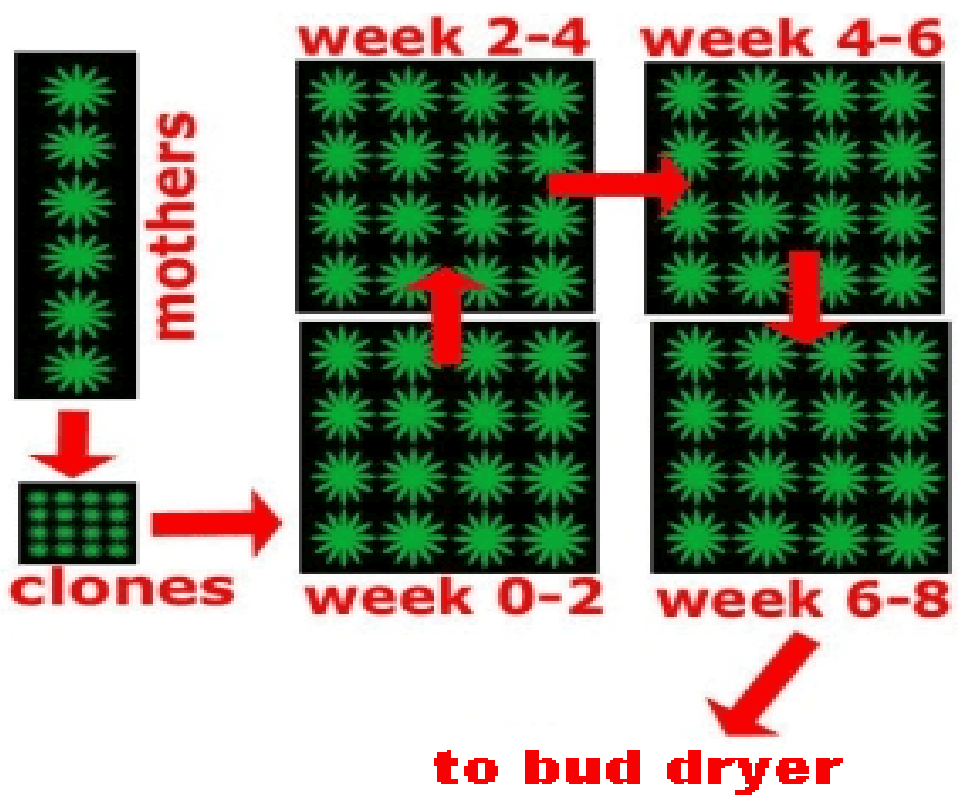

Fig. 3. Phases of vegetative cultivation of cannabis for medicinal use.

the top of the Cannabis plant (Cannabis flos) in the Mother phase and each clone planted in a separate cube; Separate premise for phase Vegetation (Fig. 3); Separate premise for stage Flowering; Separate premise for phase Mother and Separate premise Quarantine. It is recommended medical cannabis plants/herbal cannabis substances be stored in appropriate packs and in easy-toclean rooms, on pallets, with sufficient distance from the walls and well separated from other herbal substances to avoid cross-contamination (Novak and Iguera, 2019).

\section{Equipment}

The equipment and machines used for cultivation and processing plants should be made of suitable materials resistant to chemicals and other undesirable substances, regularly cleaned, maintained and calibrated as well easily accessible. Machine devices in direct contact with collected medicinal plants/herbal cannabis substances must be cleaned and disinfected before and after usage to prevent cross-contamination from the remaining residues.

\section{Personnel and training}

The protocols for the cultivation and processing of each batch of medicinal plants/herbal substances from cannabis must be certified by an educated agronomist and pharmacist and should be stored for at least a 10-year period. A lot number should be assigned on the product label. Staff should receive proper botanical training on cannabis plants. This includes the identification of collected species and botanically related and/or morphologically similar species together with an indication of whether fresh, dried or traditionally processed material is used in order to avoid any risk to public health and knowledge of the techniques of harvesting, the best time for harvesting, and the importance of primary processing to the best possible guaranteed quality (Fig. 4). All those involved in cultivation must be trained the appropriate use of herbicides and pesticides, also. The active and characteristic constituents should be specified and content limits should be defined. Foreign matter, impurities and microbial content should be defined or limited (WHO, 1996c).

\section{Hygiene}

All procedures for cultivation and primary processing should be fully complied with regional and/or national guidelines on food hygiene and hygiene of personnel. Personnel should be required to have a high level of personal hygiene and receive appropriate training in relation to their hygienic responsibilities. Staff must wear appropriate protective clothing. Persons infected from known infectious diseases that are transmitted through food and persons with open wounds, inflammations and skin infections should be removed from places where they would come into contact with medicinal plants / herbal substances of cannabis according to regional and/or national regulations.

\section{Documentation}

For cultivated medicinal plants/herbal cannabis substances, all processes must be documented, including the location, the name of the responsible agronomist and 


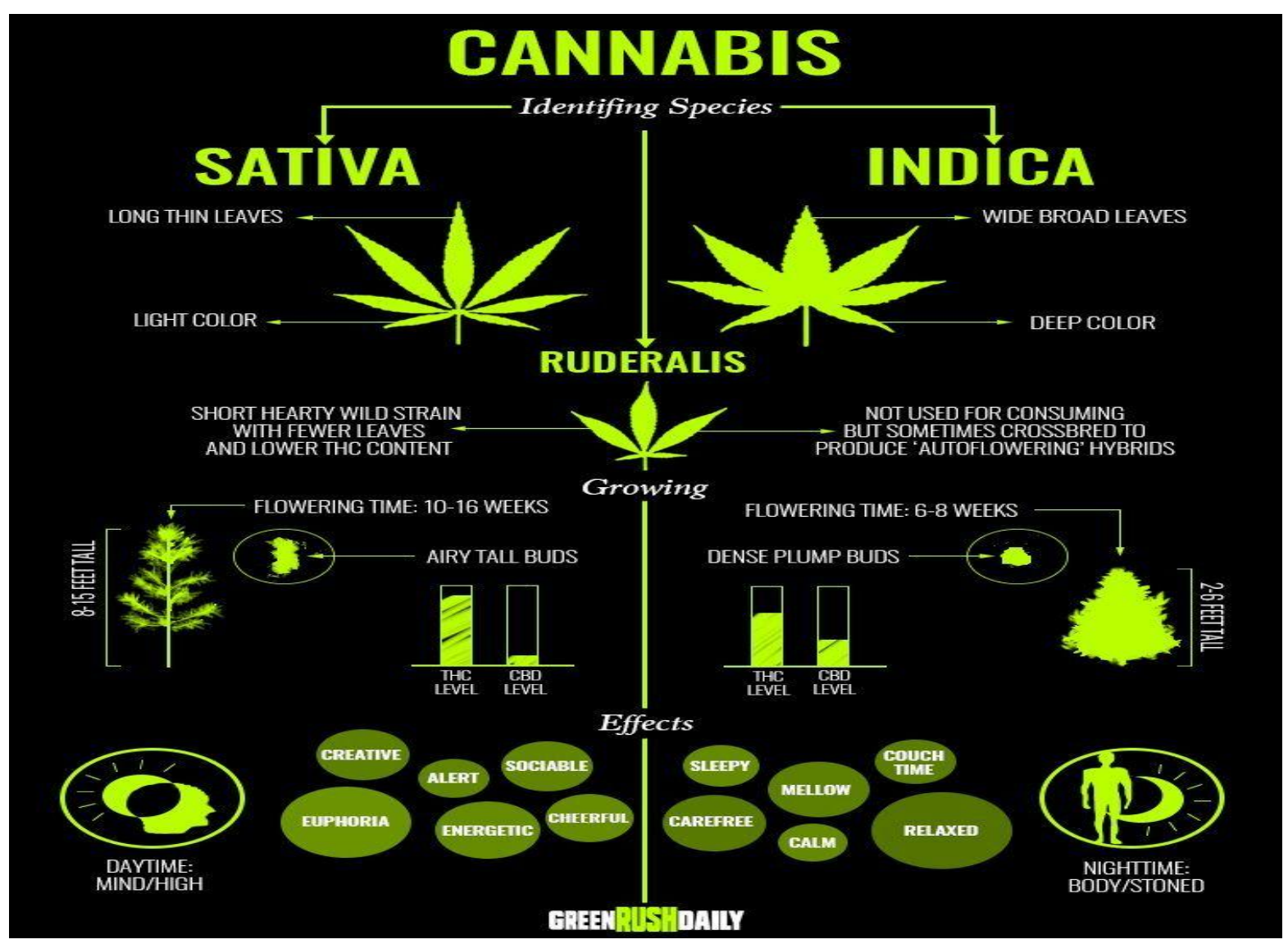

Fig. 4. Different species of cannabis for medicinal use.

pharmacist, the standard cultivation conditions, type of medicinal plants/herbal substances from cannabis, quantity and date of harvest (including harvest time), as well as the chemicals and other substances used during production, such as: fertilizers, pesticides, herbicides and growth promotors. The geographical location of collection sites and the harvest period should be described as precisely as possible. Internal checks on all records should be carried out once a year. The batch numbers of medical cannabis plant materials should be unambiguous and unmistakably linked to their origin. Therefore, proper labeling of batch delivery is required. Annual plans and reports for the maintenance and calibration of the equipment used in the production process, should be done. Soil analysis reports should be kept in an accessible place at hand. Records from internal audit reports should be kept for at least 10 years.

\section{Seeds and propagation material}

The seed should originate from precisely identified medicinal herb in terms of yield, species, variety/cultivation/chemotype and origin and should be monitored. Trimmed parts of female cannabis plants that can be used as a planting material for cannabis production, also. The starting material should be controlled on pests and diseases in order to provide healthy plant growth.

\section{Cultivation}

The principles of good cultivation must be followed, including the:

environment and the climate (the length of the day and the duration of sunlight, the water supply and the temperature);

the soil and fertility (adequate amounts of nutrients, organic matter and other elements to ensure optimum growth and quality of medicinal plants, the optimal soil conditions, including the soil type, drainage, moisture retention, fertility and $\mathrm{pH}$, depend on the selected medicinal herbs types of cannabis);

- the application of fertilizer (often necessary in order to obtain large yields of medicinal plants, but it is necessary to know the exact types and quantities of fertilizers used);

irrigation (should be controlled and implemented depending on cannabis type and subspecies for medical use and the phase of cannabis growth. 
The water used in the irrigation should be in accordance with the regional/national quality standards and should not be contaminated with fecals, heavy metals, pesticides or toxicologically hazardous substances. Plants should be shed in their roots and covered during rainy or wet weather);

- Plant maintenance and protection (may include usage of approved pesticides and herbicides but only in approved manner, in accordance with the instructions for use and regulatory requirements. Only qualified personnel using approved equipment should implement applications of pesticides and herbicides that need to be documented).

The most important factors at each stage of the process of growing/producing cannabis are: Size of each room $\left(10-50 \mathrm{~m}^{2}\right)$, temperature $\left(18-25{ }^{\circ} \mathrm{C}\right)$, fertilizers (macro and microelements, several times a day), plant protection (larvicides, potassium salts of fatty acids, hydrogen peroxide, algae, fumigation), size of cubes (variable), number of cubes $/ \mathrm{m}^{2}$ (variable), lighting (height of the luminaire) - up to $100 \mathrm{~cm}$, type of lights (LED or UV), shading and shading mode (12-18 hours illumination), induction of blossoming, time for harvest, time and temperature of drying (not more than $60{ }^{\circ} \mathrm{C}$, several days), HVAC System ventilation (at least on every 10 minutes per hour), $\mathrm{pH}$ (5-6), watering (several times a day), hygienic conditions (personal hygiene, hygiene of space, systems and tools).

\section{Harvest}

The best time for harvesting of medical plants/herbal substances from cannabis should be determined. Damaged plants or plant parts should be removed. If harvesting occurs in wet conditions and increased humidity levels, additional measures should be taken to eliminate possible adverse effects on medicinal plants/herbal cannabis substances. Collected medicinal plants/cannabis herbal substances must be transported immediately in dry, clean conditions (bags, baskets or boxes) in order to prevent thermal degradation. During harvesting, care should be taken not to mix with other plant species or different cannabis varieties and/or mixing collected medicinal herbs/cannabis with toxic weeds. All containers used during harvesting must not be contaminated from previous harvesting. The containers must be stored in dry conditions unavailable for pests. Harvested medicinal plants/cannabis herbal substances must not be compacted or mechanically damaged (bags must not be overloaded or stored in too high containers). All pest control measures should be documented.

\section{Waste management}

Waste and assessment of the risk of pollution, disposition of harmful materials and chemicals should be documented. Implementation of a written plan for waste reduction and proper dislocation outside the facility is required. Waste should be kept in such a way that it will not contaminate the growth and the environment of cannabis. If the waste is collected in bags, it must be stored in containers with a locking possibility and stored immediately.

\section{Primary processing of GMP Final product - Cannabis flos $100 \mathrm{~g}$ in-bulk in aluminum bags}

The primary treatment of raw medical cannabis plant materials includes washing, trimming, freezing, drying, curing, etc. and they must comply with regional and/or national regulations and should be implemented as soon as possible after harvesting. Upon the arrival of the collected medicinal plants/herbal substances from cannabis in the processing facility, they should be unloaded immediately and unpacked. It is recommended to make a uniform drying of medicinal plants/herbal substances from cannabis and thus avoid the creation of mold. The conditions for drying, such as temperature, duration, air circulation, etc. must be selective because of the nature of active ingredients and recorded in detail. All materials must be checked in order gaining the standard quality product.

Special recommendations for Cannabis flos production used for obtaining a standardized herbal substance

If Cannabis flos is intended for standardized herbal medicine, cannabis must be grown under such standardized conditions that the contents of the active components will be constant. The content of the main cannabinoids, which include $\Delta$-9-tetrahydrocannabinol $(\Delta-9-T H C)$ and cannabidiol (CBD), should be determined quantitatively. During drying, at least the following parameters must be standardized: atmospheric humidity, temperature, ventilation and time of drying.

\section{Packaging}

Cannabis flos for medical use should be packed in clean and dry, preferably new bags and/or boxes, made of aluminum labelled with clear, permanently fixed and made of non-toxic material labels. The information must comply with the regional and/or national labeling regulations. Packaging materials that have been previously used and are intended for reuse should be clean and dry to avoid contamination during reuse.

\section{Storage and distribution}

Dried and packaged Cannabis flos, should be stored in dry and well-ventilated areas in which the daily temperatures are controlled and have good air flow. Fresh products should be stored at a temperature of $1-5{ }^{\circ} \mathrm{C}$, while frozen products should be stored below $-18^{\circ} \mathrm{C}$ (or below $-20{ }^{\circ} \mathrm{C}$ when intended for long-term storage). In 
this case of bulk transport, it is important to provide dry conditions and to reduce the risk of mold production or fermentation and it is recommended to use open transport containers with sufficient air flow. For the fumigation of the warehouses, only substances permitted by regional and/or national provisions may be used.

\section{Safer storage of the material}

The facility in which cannabis is grown, processed, packaged and stored must be well secured. This means that there must be physical security, monitoring and approved access in the facility only to authorized persons. Employees involved in the cannabis storage process must be authorized by the employer to carry out that activity.

\section{Product consideration - investigation}

The manufacturer has a documented traceability system, a withdrawal plan, a withdrawal test, and a standard procedure for managing complaints and recalls.

\section{GLP - Quality control - Laboratory tests.}

All laboratory tests should be carried out in accredited laboratories according to ISO 17025 or by authorized national authorities. All laboratory results should be kept for at least 2 years. Each batch is required to be analyzed. According the specification, appearance is brownish - green grouped flowers of $1.5-3 \mathrm{~cm}$ with characteristic odor, microscopically corresponds to a microscopic monograph mainly with trachoma, identification of active ingredients: THC, CBD, CBN, pesticides - GC+LC, microbiological tests, total number of microorganisms, molds and yeasts, Escherichia.Coli, Streptococcus aureus, Salmonella, Pseudomonas, $\mathrm{Pb}, \mathrm{Hg}$, As, Ni, Zn., Aflatoxin-B1, Total -Aflatoxins (B1, B2, G1, $\mathrm{G} 2)$.

\section{Different approach to the application of GACP and GMP in production of Cannabis flos}

Good Agricultural Practice and Collection Practices (GACP) refer to the cultivation and collection of medicinal plants, including certain post-harvest activities. The main goals of these guidelines are: contribution to the quality assurance of medicinal cannabis plant materials used as a source for herbal medicines aimed at improving the quality, safety and efficacy of finished herbal products, formulation of national and/or regional guidelines and monographs of the GACP for medicinal cannabis plants and related operational procedures, encouraging and supporting the sustainable cultivation and collection of medicinal cannabis plants of good quality while protecting the medicinal plants and the environment in general.

GMP is an integral part of the organization's quality management system (QMS). It is designed to minimize the risks involved in all steps of the production process. Successful implementation will ensure the effectiveness, accuracy and consistency of the finished product over time. Although GMP includes final testing of products in certified quality control laboratories, they are insufficient. GMP is intended to be implemented throughout the whole life cycle process, from raw materials sources and examining the qualifications of external suppliers, until a final product with an approved shelf life is obtained. It must be embedded in each batch of product throughout all stages of the production process. GMP actually covers all aspects of the production process. These guidelines provide minimum requirements that the manufacturer must meet to ensure that the products are of high quality and do not pose a risk to the consumer. Guidelines generally become the basis for regulation of that industry.

The API is the active ingredient that is the starting material for the manufacturing process of the finished product. For medicinal cannabis, the API could be an extracted and purified active component of the cannabis plant (for example a cannabinoid) or an extract of specified parts of the cannabis plant or powdered specified parts of the cannabis plant (TGA Health Department, 2008).

According to GMP Guideline, Cannabis flos for medicinal use $100 \mathrm{~g}$, in-bulk, packed in aluminum bags is intended to be Active Pharmaceutical Ingredient (API) that is the starting material for the manufacturing process of the cannabis extracts for medicinal use. API production is required to be in accordance with Part II of the PIC/S Guideline which provides process steps where GMP is expected to be applied more. GMP implementation in the cannabis industry is relevant for: primary processing, materials, methods, facilities, equipment, personnel, controls, manufacturing, packaging, storage, documentation and transport.

In addition to clinically proven medical potential, cannabis preparations differ significantly from most conventional pharmaceuticals because the toxicity of manufactured products is very low. GMP standards should be implemented in the cannabis industry. Cannabis is considered a medicine and must therefore comply with the same regulations governing the pharmaceutical industry, and GMP/GACP certification is one of them. If it is not implemented, this may be the reason for a lost sale, i.e. a way to distinguish the supply of a product manufactured in accordance with the GMP/GACP standards and to be placed on the market as superior to non-GMP-produced cannabis derivatives (Table 1).

\section{Primary processing, drying and trimming cannabis for medical use}

The previous sections examined the various requirements of GACP and GMP, but to be ready for GMP standards, the Primary Cannabis processing as drying, trimming, packing and storage of Cannabis flos $100 \mathrm{~g}$, in-bulk packed in aluminum bags, the following five aspects must be completed:

Макед. фарм. билт., 66 (1) 91 - 101 (2020) 
handling medicinal plants. Toilets should be ventilated and, where appropriate, warmed. Whenever the process requires, proper and comfortable hand washing facilities and hygienic drying facilities should be provided (Government of Canada, 2015)

Equipment used for the manufacture, packaging, labeling or control of herbal substances and cannabis products for medical use should be designed, constructed, maintained, operated and fitted in such a way as to enable effective cleaning of all surfaces; to prevent contamination of the drug; and work according to the purpose (log-books for usage, maintenance and cleaning). The Equipment Sanitization Program includes SOPs for cleaning the equipment. Critical areas that are most difficult to clean should be identified. Equipment cleaning procedures must be validated. Microbiological contamination should be prevented, rather than removed. Ideally, an organization will aim to establish simple standard operating procedures implemented by thoroughly trained and experienced staff. The equipment for producing, packing, labeling or analyzing batches of herbal substances and cannabis products for medical use should be designed, constructed, maintained, operated and located in such a way as to enable effective cleaning of its surfaces; prevents contamination of the drug and the addition of external material in the drug; and allows it to function in accordance with its purpose. Regular maintenance and records are essential.

Personnel according to their duties and responsibilities must have adequate technical, academic and similar training, and be competent, in the interests of the health of the consumer or the buyer. Management is responsible for providing adequate resources (materials, personnel, facilities and equipment). It must constantly monitor and improve the efficiency of the pharmaceutical quality system. It is essential, skilled personnel to supervise the production of herbal substances and products from cannabis for medical use. These operations are very technical in nature and require constant alertness, attention to detail and high degree of competence of employees. Ideally, an organization will aim to establish simple standard operating procedures implemented by thoroughly trained and experienced staff.

Sanitation as part of GMP compliance. Sanitation in the production of cannabis medicines helps ensure that products are safe for consumption. The written sanitation program provides some assurance that the plant's cleanliness levels are maintained and that the relevant regulatory provisions are met. Cleaning procedures are validated. Microbiological contamination should be prevented, rather than removed. There must be a written sanitation program (cleaning requirements applicable to all product areas, cleaning requirements, cleaning intervals, cleaning agents, responsibilities, cleaning validation) which must be carried out under the supervision of qualified personnel.

Cleaning Validation Guidelines - The purpose of the cleaning validation is to verify the effectiveness of the cleaning procedure to remove residues from products, degradation products, preservatives, aids and/or cleaning agents, as well as control of potential microbial contaminants. In addition, it should be ensured that there is no risk associated with cross-contamination of the active ingredients. Validation for cleaning the equipment can be carried out simultaneously with the actual steps of production, during process development and or clinical production and should be continued through full commercial production. The validation of cleaning processes should be based on the worst-case scenario and at least three (3) consecutive cleansing charges should be performed and proved to be successful in order to prove that the method has been validated. Detailed cleaning procedures should be documented in the Standard Operating Procedures (SOPs). A cleaning check protocol is required to define how the cleaning process will be checked, including detailed cleaning procedures for each product, each production system, or each piece of equipment. When more complex cleaning procedures are required, it is important to document critical cleaning steps. In that sense, specific documentation should be available for the equipment itself, which includes information on who cleaned it, when cleaning is done, the product previously processed on the equipment that is being cleaned. However, for relatively simple cleaning operations, the documentation for the entire cleaning process may be sufficient. Timeframes for the storage of unclean equipment should be established before the start of cleaning, as well as the time limits and conditions for keeping clean equipment.

There are two common types of sampling that are considered acceptable, direct picking from surfaces (swab method) and indirect sampling (use of rinse solutions).

Direct sampling - The locations that are most difficult to clean, and which are reasonably available can be assessed by a direct sampling method, leading to the level of contamination or residue on a given surface

Rinse samples - for large-surface sampling and inaccessible systems or those that cannot be routinely disassembled. However, consideration should be given to the fact that the residue or pollutant may be insoluble or may be physically covered in the equipment. When detergents are used in the cleaning process, their composition should be known to the user and their removal should be demonstrated.

The suitability of the material used for sampling and the sampling medium should be determined. The selection of the sampling material may affect the accuracy of the sample. It is important to ensure that the sampling medium and the solvent (used to extract from the medium) are satisfactory and can be easily used.

Documentation should supply traceability in all processes and procedures that could affect the quality of the product. The maintenance and cleaning records must be filled in. The conditions of drying, the processes of 
labeling, packing, batch delivery, storage as well as annual plans and reports for the maintenance and calibration of the equipment used in the production process, should be documented. Internal checks on all records should be carried out once a year. The results of the internal inspections should be documented in an internal audit report (copies of all documents, audit reports, analysis reports, etc.) and should be kept for at least 5 years. GMP certification for the production of cannabis and cannabis preparations is through an authorized regulatory authority (the National Agency for Medicinal Products and Medical Devices).

\section{Conclusion}

The basic requirements of the GMP program can be summarized as follows:

- Processes of production are clearly defined and controlled to ensure consistency and compliance with approved specifications and procedures;

- Validation of the critical steps in the production processes and significant changes in the process;

- Work instructions and procedures should be written in a clear and easily understandable way;

To provide all necessary key elements for GMP, including qualified and trained personnel, appropriate premises and space, appropriate equipment and services, proper materials, containers and labels, approved procedures and instructions, appropriate storage and transport (Mobius Trimmer, 2019).

\section{References}

Government of Canada, 2015. Good Manufacturing Practices. Available at: https://www.canada.ca/en/healthcanada/services/drugs-health-products/ complianceenforcement/good-manufacturing-practices.html (Last accessed: 15 March 2019).

EudraLex, 2009. The Rules Governing Medicinal Products in the European Union Volume 4: EU Guidelines for Good Manufacturing Practice. Medicinal Products for Human and Veterinary Use Annex 7: Manufacture of Herbal Medicinal Products. Available at: https://ec.europa.eu/health/documents/eudralex/vol-4_en.
European Medicines Agency Evaluation of Medicines for Human Use, 2006. Guideline on good agricultural and collection practice for starting materials of herbal origin. Available at: https://www.ema.europa.eu/en/documents/scientificguideline/guideline-good-agricultural-collection-practicegacp-starting-materials-herbal-origin_en.pdf (Last accessed: 20 March 2019).

Ministry of Health, Labour and Welfare Ed. Yakuji Nippo, 1992-2001. Cultivation of medicinal plants and quality control, Vol. 1-10.

Mobius Trimmer, 2019. The ultimate Guide to AGMP-certified cannabis workflow. Available at: https://www.mobiustrimmer.com/gmp-certified-cannabistrimming/ (Last accessed: 20 March 2019).

Novak, J., Iguera, R., 2019. Good Agricultural and Wild Collection Practice (GACP) of Medicinal Plants in Europe. Available at: http://doclinika.ru/wpcontent/uploads/2015/10/Novak.pdf (Last accessed on 20 February 2019).

TGA Health Department, 2008. Guidance on GMP compliance for the manufacture of medicinal cannabis for supply under 'approved access' provisions 13, 2-11.

World Health Organization, 1996a. Good manufacturing practices: supplementary guidelines for manufacture of herbal medicinal products, in: WHO Expert Committee on Specifications for Pharmaceutical Preparations, thirtyfourth report, Annex 8 No. 863. Available at: http://digicollection.org/hss/fr/d/Js5516e/18.html\#Js5516e 18.

World Health Organization, 1996b. WHO guidelines on good agricultural and collection practices (GACP) for medicinal plants. Available at:

https://apps.who.int/iris/bitstream/handle/10665/42783/92 41546271.pdf?sequence $=1$.

World Health Organization, 1996c. Guidelines for the assessment of herbal medicines, in: WHO Expert Committee on Specifications for Pharmaceutical Preparations. thirty-fourth report, Annex 11 No. 863. Available at: http://digicollection.org/hss/en/d/Jh2984e/.

World Health Organization, 1998. Quality control methods for medicinal plant materials. Available at: https://apps.who.int/iris/handle/10665/41986.

World Health Organization, 2003. Good Manufacturing Practices for pharmaceutical products: main principles, in: WHO Expert Committee on Specifications for Pharmaceutical Preparations, thirty-seventh report, Annex 4, No. 908. Available at: https://gmpua.com/World/WHO/Annex4/trs908-4.pdf. 


\title{
Резиме
}

\section{GMP/GACP - нови стандарди за осигурување на квалитетот на канабис}

\author{
Мирела Илиќ ${ }^{1 *}$, Ирена Брчина ${ }^{1}$, Лилјана Угринова ${ }^{2}$, Васил Карчев $^{2}$, \\ Александра Грозданова ${ }^{3}$
}
${ }^{I}$ NYSK Холдинзи-Скопје, Индустрија за екстракти и фармачевтски дозирани форми со канабис за медицинска употреба, Индустриска зона Којлија, опитина Петровеи, 1000 Скопје, Северна Македонија
${ }^{2}$ Институт за применета хемија и фармацевтски анализи, Фармацевтски факултет, Универзитет,,Св. Кирил и Методиј”, Мајка Тереза 47, 1000 Скопје, Северна Македонија
${ }^{3}$ Институт за фармацевтска хемија, Фармаиевтски факултет, Универзитет „Св. Кирил и Методиј”, Мајка Тереза 47, 1000 Скопје, Северна Македонија

Клучни зборови: GxP, GMP, GACP, GLP

Во 2015 година, во Република Северна Македонија, усвоен е нов закон за наркотици, каде што измените вклучуваат законско одгледување на канабис за медицинска употреба, како и легално производство на екстракти од канабис за медицинска употреба. За да се добијат канабис и производи од канабис за медицинска употреба со висок квалитет и да се исполнат некои стандарди за квалитет што ќе гарантираат конзистентност, следливост и континуиран квалитет на производот, потребно е да се имплементираат системи за квалитет. Покрај ISO стандардите, за канабис за медицинска употреба, начесто се користат GACP, GMP и GLC стандардите. Производството на канабис за медицинска употреба се состои од: процес на одгледување каде што се применуваат GACP стандардите, примарна обработка каде што се најважни GMP стандардите и контрола на квалитет на финалниот производ регулирани со GLP стандардите.

Во овој труд, даден е опис и објаснување на овие стандарди, како и детален преглед на начините на нивно спроведување. 
